\title{
Integrated Interpretation of Geophysical and Soil Geochemical Anomalies in Gold Exploration: Case of Kouremale, Southern Mali-West Africa
}

\author{
Fodé Tounkara $^{1,2^{*}}$, Jianguo Chen ${ }^{1}$, Souleymane Keita ${ }^{3}$ \\ ${ }^{1}$ Faculty of Earth Resource, China University of Geosciences, Wuhan, China \\ ${ }^{2}$ Department of Geology, ENI-ABT, Bamako, Mali \\ ${ }^{3}$ Department of Hydrology and Water Resources, School of Environmental Studies, China University of Geosciences, Wuhan, China \\ Email: ^fode1986@yahoo.fr
}

How to cite this paper: Tounkara, F., Chen, J.G. and Keita, S. (2017) Integrated Interpretation of Geophysical and Soil Geochemical Anomalies in Gold Exploration: Case of Kouremale, Southern Mali-West Africa. International Journal of Geosciences, 8, 1133-1145.

https://doi.org/10.4236/ijg.2017.89065

Received: July 10, 2017

Accepted: September 13, 2017

Published: September 26, 2017

Copyright $\odot 2017$ by author and Scientific Research Publishing Inc.

This work is licensed under the Creative Commons Attribution International License (CC BY 4.0).

http://creativecommons.org/licenses/by/4.0/

(c) (i) Open Access

\begin{abstract}
Detecting the anomalies' sources location in the vast territory such as Kouremale area is a grand challenge for geophysicists because there is a need to assess gold deposit. Therefore, this paper aims to recommend a methodological approach on applied magnetic survey and soil geochemistry to identify the location of anomalies' sources. To that aim the study is divided into phases. In the first phase, the maps for integrated interpretation have been produced by Geosoft Oasis and ArcGIS 10.2.1. The corrected and processed magnetic data with eliminated diurnal variation have been used. Phase two consist of integrate geochemical soil map. The results of phase one identified four magnetic anomalies zones (MAZ) with their coordinates. Thus, the obtained radiometric map, showed that there is a high intensity of $\mathrm{K}$ and Th compared to $\mathrm{U}$, which indicates a significant weathering process and there are many saprolithes in study area. The findings of phase two revealed that there is a high concentration of gold content $(1500 \mathrm{ppm})$ with an average concentration of $92 \mathrm{ppm}$. The integrated interpretation map coming from the combined different maps, referring to the geological information verified on the field, led to conclude that, the target $\mathrm{B}$ is the best gold anomaly. The delimitation of the space of the target $\mathrm{B}$ from the geophysical and geochemical information confirmed the existence of limited, restricted and potential anomaly.
\end{abstract}

\section{Keywords}

Anomalies Geophysical, Integrated Interpretation, Kouremale, Soil Geochemistry 


\section{Introduction}

Identifying the location of anomalies' sources in a vast territory such as Kouremale area of Mali is a grand challenge for geophysicists because the economic evaluation and concentration of gold have to be defined in this area, which is a famous area for gold panning activity. This informal gold exploitation makes up an important activity and a source of incomes for the inhabitants of the town of Kouremale situated between the Mali-Guinea borders. Gold mining in Mali has a long history [1]. The birimian rocks are major sources of gold in Mali according to Geological synthesis of the birimian in Mali [2]. The main purpose of this study is to contribute to find a potential area of gold anomaly. However, gold deposit exploited in the syama in southern MALI occur along a north-northeast trending mineralized litho-structural corridor that trends for approximately 40 $\mathrm{km}[3]$.

\section{Geological Setting and Location of Study Area}

The Kouremale area situated in south of Mali, is a part of the geological subdivision of the Yanfolila area (Figure 1) in the southern desert of Sahara (West Africa). A geological map (Figure 1) made at the scale of 1/50000 sums up the geological information especially the characteristics of the birimian [4] which

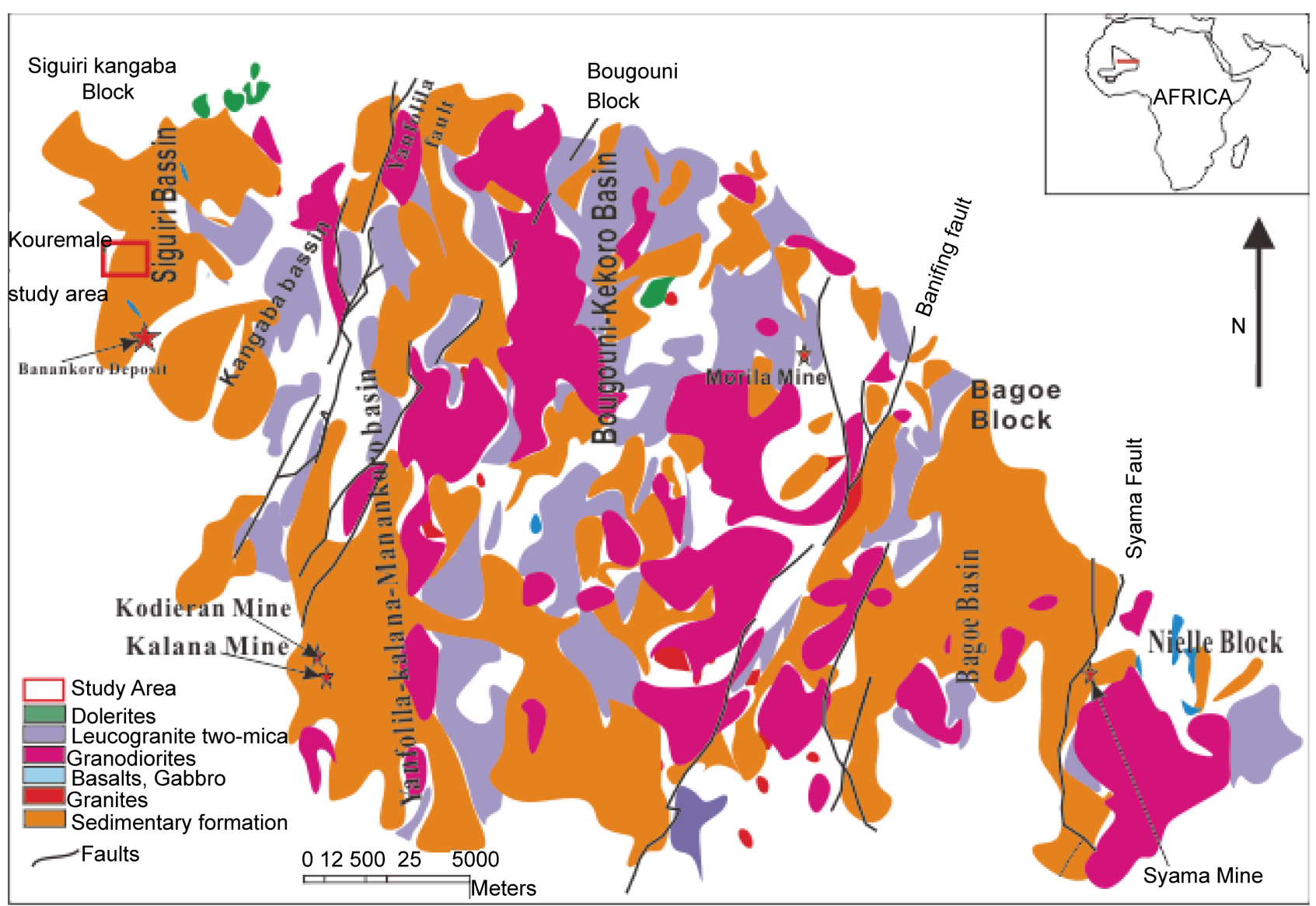

Figure 1. Regional geological map (source DNGM). 
has been defined in the valley of the river birrin around the twenties. The following map below (Figure 2) describes the geological aspects of the study area and presents the different types of rocks and the geographical delineation of the study area. The kouremale sector is located at the border Mali-Guinea, $150 \mathrm{Km}$ in the South of Bamako the capital of Mali, connected by the national highway number 5. In the town of kouremale, the production of cereals and cotton are the main economic activities of people, yet gold panning is becoming a good way to increase the inhabitants' incomes [5].

The south birimian belongs to the Precambrian in the vast West African craton located between the shield Man (South) and the dorsal Reguibat (North). The southern Mali geology where the study area is located is made up of birimian and volcano-sedimentary rocks affected by a low-grade metamorphism occurred during the orogeny Eburneen $(2.1 \mathrm{Ga})$ and some intrusions appearing during and after the orogeny. The south of Mali is bordered by the Taoudeni basin. According to Geological synthesis of the birimian in Mali, 2006 the birimian rocks are made up fine grained sedimentary and volcanic rocks. The sedimentary sequence is constituted of meta-arenites, metaargilites, metagreywackes and carbonates. The volcanic formation is made up of tuffs, andesites, basalts and dacites. In the north east, the fault Banifing, the most significant within the south of Mali has a left lateral displacement with several parallel shear zones, This structure is $500 \mathrm{Km}$ long. We also have the gold province constituted of Kalana and kodieran. The gold fields of southern Mali are located over an anticline oriented north south, which is $150 \mathrm{Km}$ long and $40 \mathrm{Km}$ wide crossed by three faults systems (see Figure 1). Some massive granites [6] and intrusive dolerites appear within this area Identification of the rocks komatiites and
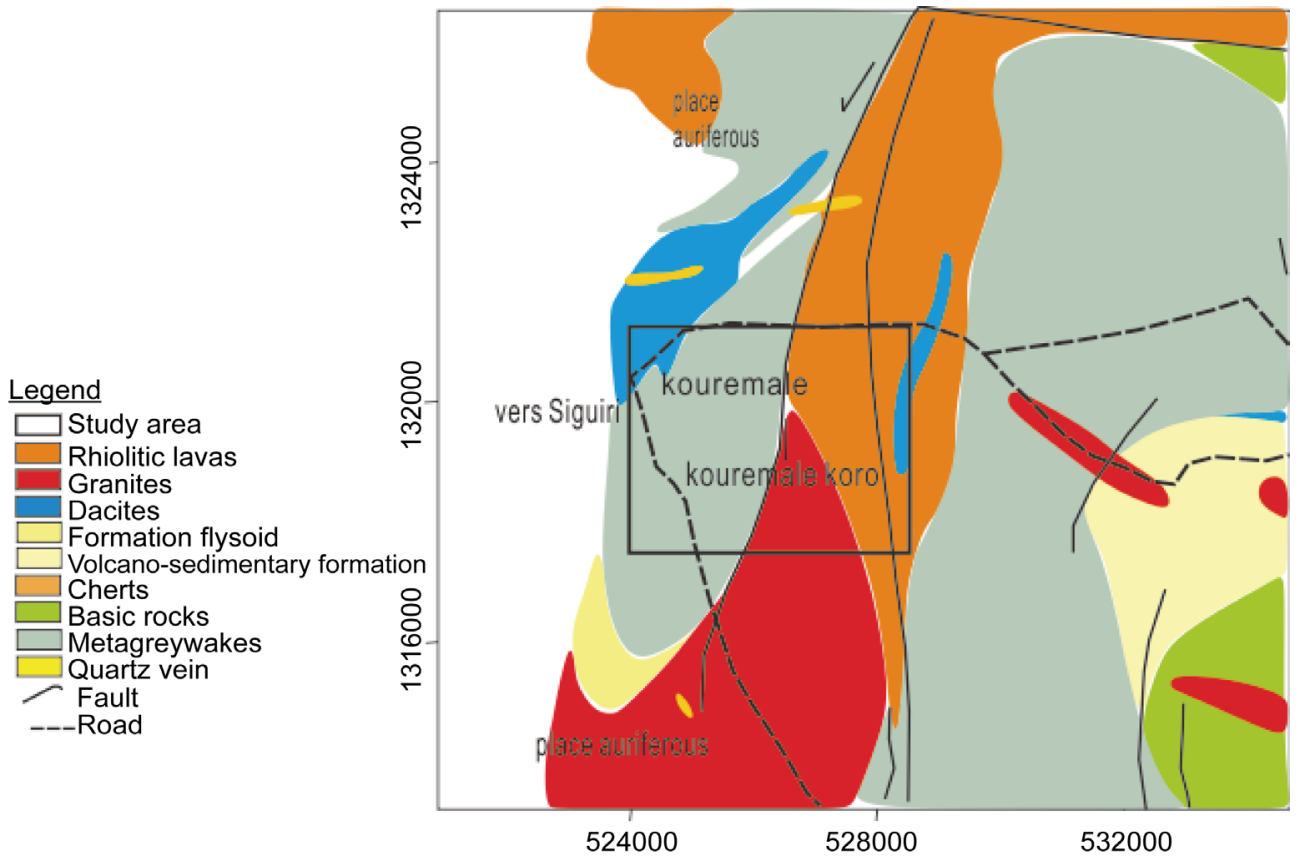

Figure 2. Geological map of Kouremale with the study area (source DNGM). 
lamprophyre in the field of kalana [7]. The intrusive rocks are classified according to their petrography (characteristics, composition and morphology).

\section{Materials and Method}

To reach this goal, the processing and interpretation of magnetic data of the studied area are required. Then, reliable geochemical and geological information require the understanding of West African craton.

In order to obtain $2 \mathrm{D}$ integrated interpretation image of anomaly source by using softwares. The geophysical and geochemical data collection and elaboration performed by the company EUREKA GEO as part of the exploration project of Kouremale.

Two magnetometers GSM-19 units, the first is maintained fixed in a defined point all over the duration of the survey, to measure temporal variations of magnetic field at regular time intervals (1 second). The second magnetometer utilized to measure the earth magnetic field variations with respect to the survey lines covering study area. The geographical positioning of the measurements ensured by a GPS composed of two units.

The first is set at a reference point called station basis, with a known coordinates, whereas the second displaced at different measuring points of the magnetic field. The following step of the first task was to correct and process the magnetic data by eliminating the diurnal variations to produce maps for interpretation by using Geosoft Oasis and ArcGIS 10.2.1.

The second step is to manage the geochemical data of the soil obtained from the SYSMIN project.

\section{Results and Discussion}

\subsection{Geophysical Map}

The data processing results compiled by the software are displayed on maps format such as the geophysical anomalies map (Figure 3). Using of the Th, K, and $\mathrm{U}$ anomaly maps proves the existence of these elements via radiometric data, deduce nature of the rocks predominate and alteration type in our study area.

Potassium (i.e. K) anomaly map on (Figure 4), thorium (i.e. Th) anomaly map on (Figure 5), uranium (i.e. U) anomaly map (Figure 6), ternary images map on (Figure 7), after the inspection of the total field map in the sector, it is processed to get a geophysical anomalies map (Figure 3).

There are four magnetic anomalies zones (MAZ) that we can be identified with their coordinates (Table 1).

In fact the measured values of the total field intensity are characterized by a significant variation compared with an average bottom level having an order of magnitude of 326240 nanotestla from green to yellow. The total field intensity oscillations are intense at the MAZ2 and MAZ4 zone and very low at ZAM3 as shows the magnetic relief.

In the MAZ1 zone, we notice in addition to their high intensity, the earth 


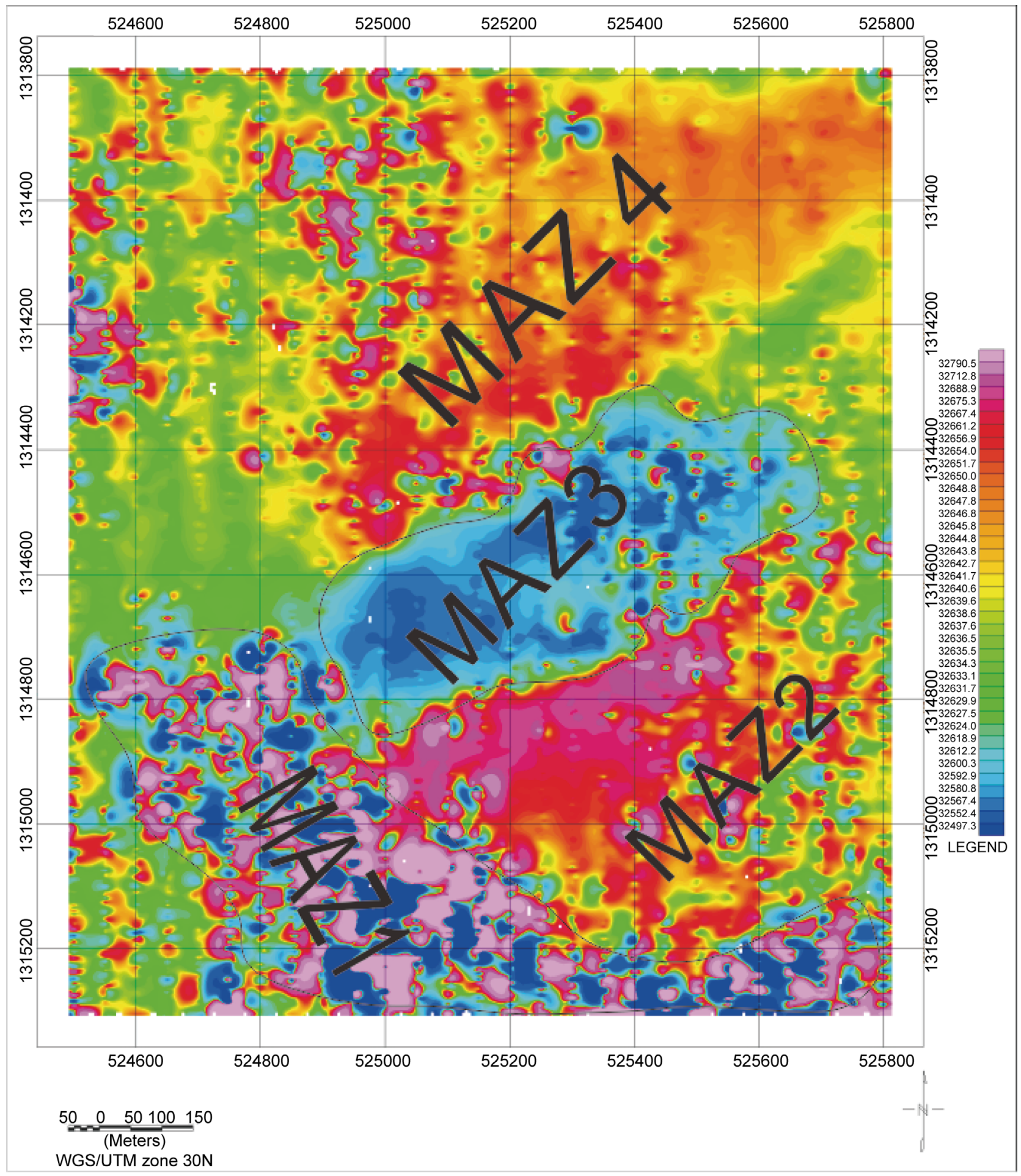

Figure 3. Geophysical map showing the magnetic field intensity in a portion of the study area with identification of four magnetic anomalies zones (MAZ1, MAZ2, MAZ3, and MAZ4).

magnetic field variations are relatively complex, because of a high disturbance and irregularities of the magnetic contours are observed. The oscillations define the anomaly having globally an elongated shape towards NE-SW direction.

The magnetic signature of the sector is characterized by the existence of these 


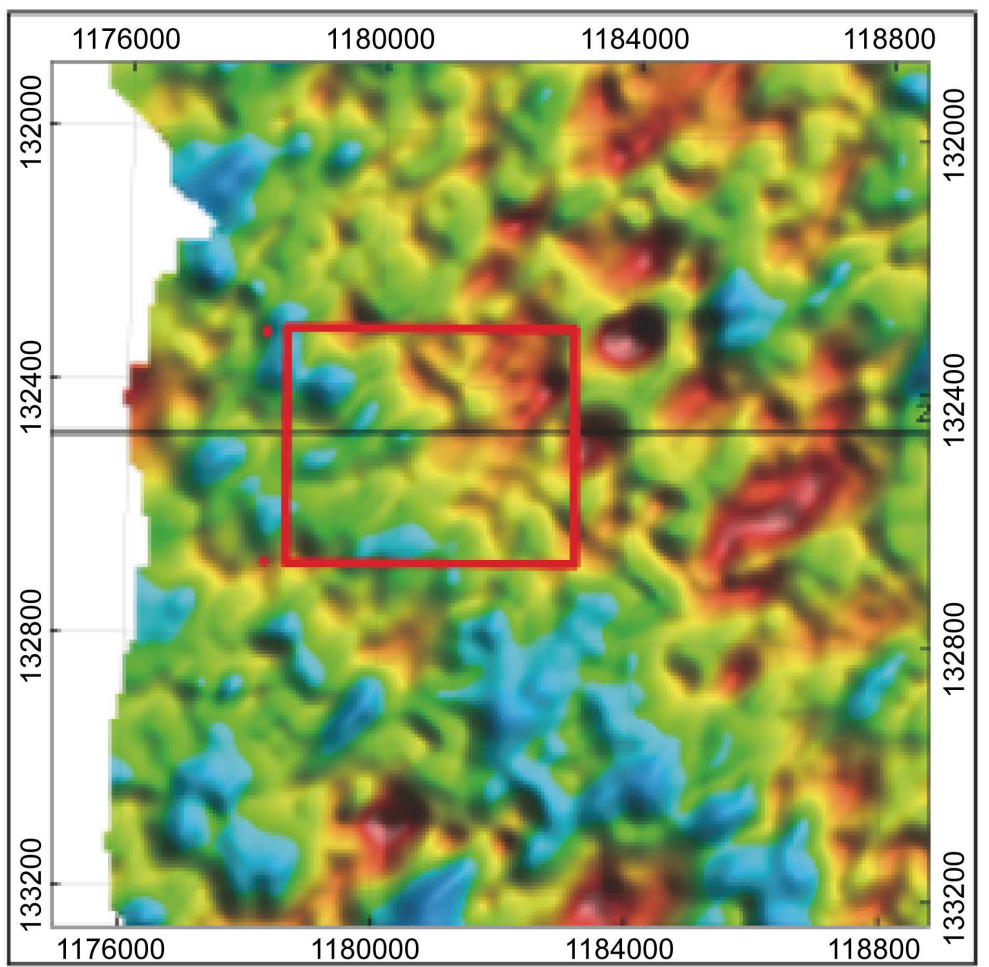

Figure 4. Spectral radiometry of thorium.

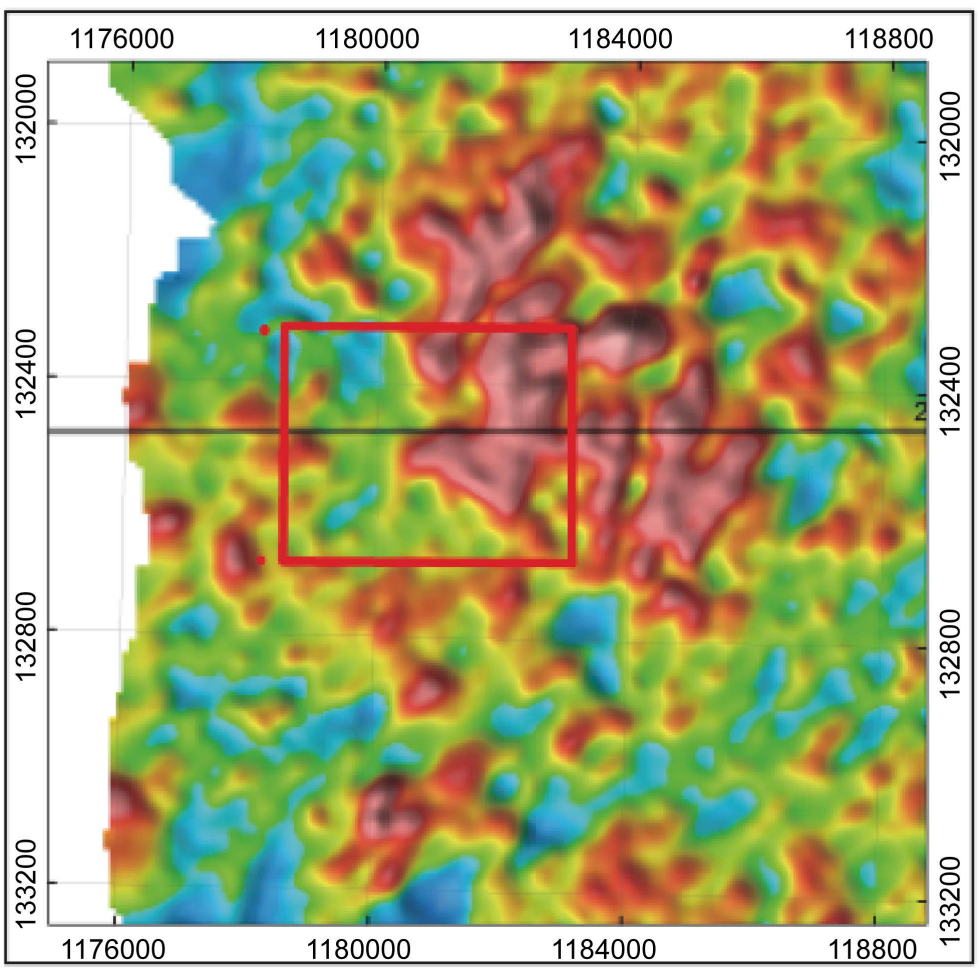

Figure 5. Spectral radiometry of uranium.

four zones located respectively in the prospected area of Kouremale. In spite of the low magnetic signatures in the MAZ3, the high variations of the magnetic 


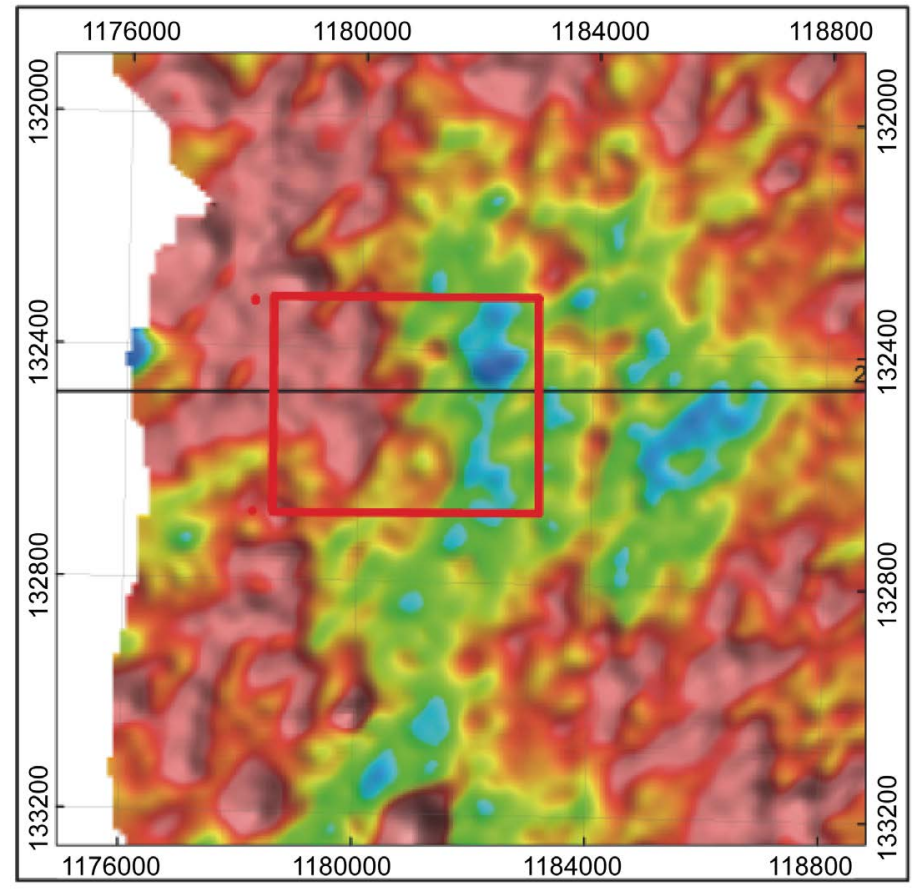

Figure 6. Spectral radiometry of potassium.

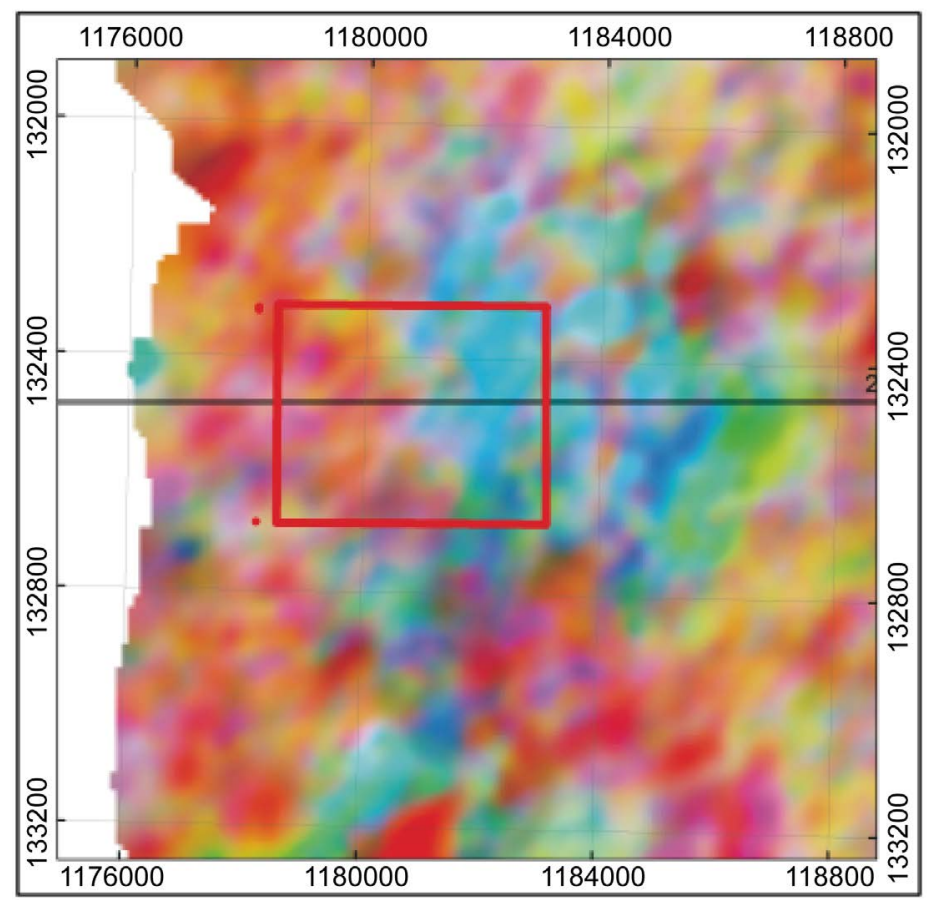

Figure 7. Aspect of ternary image.

field are registered in the magnetic zone MAZ2 and MAZ4.

However, in magnetism, susceptibility contrasts between sedimentary rocks are generally weak, so they do only produce negligible anomalies. The anomalies observed by the magnetic survey come from crystalline or metamorphic rocks [8]. 
Table 1. Coordinates of different Magnetic anomalies zones.

\begin{tabular}{ccccr}
\hline $\begin{array}{c}\text { Magnetic } \\
\text { anomalies zones }\end{array}$ & MAZ1 & MAZ2 & MAZ3 & MAZ4 \\
\hline Eastings & $52400-525480$ & $525600-52800$ & $52500-525600$ & $52500-525800$ \\
Northings & $1313800-1314200$ & $131800-1314400$ & $1314400-1314600$ & $1314800-1315200$ \\
\hline
\end{tabular}

These zones constitute a potential area to be explored due to the convergences noticed between different anomalies (Figure 8).

However, analysis of the Th, $\mathrm{K}, \mathrm{U}$ anomaly maps proves the existence of these elements via radiometric data will permit to define some structures and correlate them with those being defined by the magnetic data [9].

The abundance of these gamma-rays will depend on the geology rocks. For example, limestone units are characterised by high values in uranium, whereas shale and grit units are characterised by higher levels of thorium.

In excess of fifty radioactive isotopes occur naturally, three of these isotopes emit gamma-rays of sufficient intensity to be of use during aerial surveying, potassium (40K), thorium (232Th) and uranium (238U) [10].

The ternary image, such as illustrated by the (Figure 7) is performed by a primary color assigning to each of the abundance of the radioelements. Therefore, potassium is assigned to red, thorium is assigned to green and uranium is assigned blue. Count rate total count is used to assign an intensity scale for each of these elements $(\mathrm{U}, \mathrm{Th}, \mathrm{K})$ and the resulting colors. The aspect of the plan indicates that the red and green are too high relative to blue depending on the dimension of study area. Which means high intensity of $\mathrm{K}$ and Th compared with $\mathrm{U}$ and a very important erosion and there are many saprolithes in the locality of Kouremale.

The different colors on the map correspond closely to some different types of rocks collected and described in the study area [11]. According to geological study, we were able to deduce the nature of the rocks predominate in our study area, so it is acid to intermediate igneous and siliceous clastics.

In general, the important of radiometric surveys is for the discovery of uranium deposits but also further note that radiometric surveys can be effectively used for mapping alteration zones [12].

Therefore, potassic alteration often results in the elevated $\mathrm{K}$ radiation particularly for mafic rock, and then anomalous $\mathrm{K} / \mathrm{Th}$ ratios along local shear or fracture zones (Figure 2) may be indicative of gold-bearing mineralization. For high $\mathrm{U} / \mathrm{Th}$ ratio within meta-sedimentary units may indicate sulphidization. Variation of U/Th ratios largely reflects the environment condition during the primary diagenesis or a later deformational phase mainly the decrease in Th radiation close to sulfide mineralization seems to be responsible for the elevated U/Th ratios [13].

By analyses of aeromagnetic anomalies [14], the relative contents of radioelements in rocks are changed in the same hydrothermal processes and partly for the same reasons as the ferromagnetic minerals [14]. 


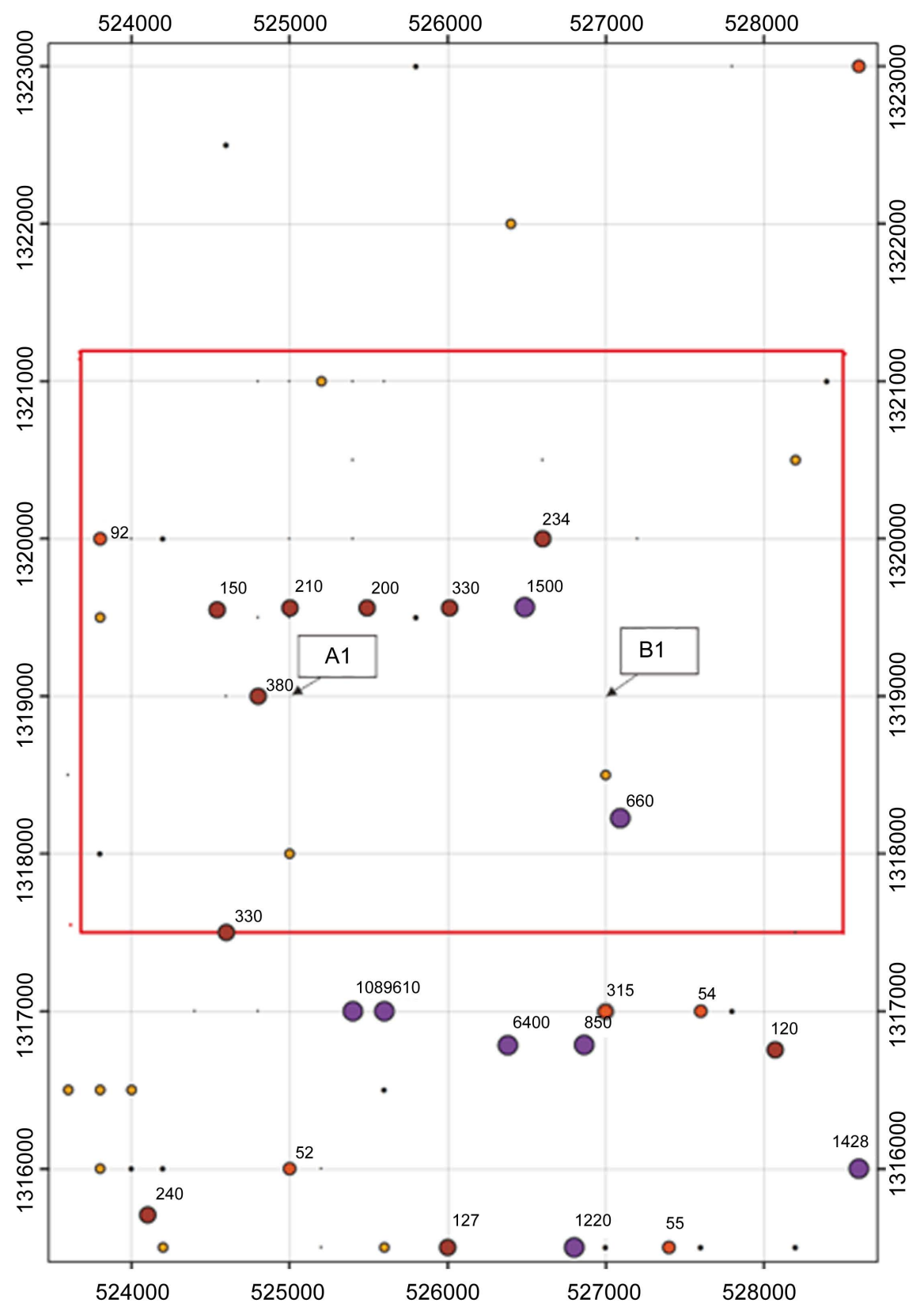

Figure 8. Soil geochemical map of the study area with target A1, B1 and gold content (ppm).

\subsection{Soil Geochemistry Map}

After the study of magnetic and radiometric maps, soil geochemical map of the study area is on (Figure 8). The gold samples taken at ground level from 10 to 30 $\mathrm{cm}$ deep. Those gold values (ppm) are presented on map.

The distribution of gold in soil samples explains that, the area has a high concentration of the gold content $(1500 \mathrm{ppm})$ and an average concentration of the gold content $(92 \mathrm{ppm})$. The average coordinate of target point A1 and B1 is also presented on the geochemical soil map and useful to correlate with geophysical maps. 
The soil geochemistry with the representation of the gold content in ppm and the magnetic anomaly maps based on the knowledge of the local geology has enabled us to identify two prospects targets A and B with their Coordinates (Table 2).

According to study research, the mineralization of gold is predominant in the greenstone belts birrimian volcano sedimentary located in the south and western parts of MALI [15]. For example the yatela gold deposit reflects lengthy process and associated karstification [16].

In order to enhance the superficial geochemical signature of gold, comparative study different mapping techniques such as the isocentration of mono-element mapping is useful such as gold element [17]. Soil type, land cover and sample size all played important roles in determining soil chemical concentrations and anomalies features.

However, the influences from other factors were still evident. Attempts made in this study show that it remains a challenging task in geochemistry to separate all the factors and to model their influence at the regional scale [18].

Useful also in order to assist the readers in following the interpretation of the soil geochemical data in relation to bedrock, the lithological boundaries. A map produced come from a combination of soil geochemical, airborne radiometric data sets, which are superimposed [19].

The area of the soil geochemical anomaly is coincident respectively to magnetic anomalies zones illustrate in the following Figure 9 which explains that the geochemical anomaly confirms the geophysical anomaly.

In addition to the radiometric data to understand, weathering linked to geochemical anomalies.

A clear vision over the anomaly origin within the study zone and the average coordinates; we confirm that the MAZ corresponds with the target A and B. The magnetic lineaments observed in this study shows a different orientation represented on the integrated interpretation map (Figure 9) synthetizing the results obtained from the previous analysis of the magnetic data needed to provide some guidelines for future gold exploration projects in the area. A choice between the two targets has to be made for the research continuity.

However some advanced research as study of multi-parameter (resistivity, density, porosity, velocity) borehole geophysical measurement is necessary [20] to know the physical rock property data in the target $\mathrm{A} 1$ and $\mathrm{B} 1$.

Application for ERI (electrical resistivity imaging) calibrated according [21] to geomorphogical, hydrological and geochemical data is useful, in order to translate and help to understand geophysical information.

Table 2. Coordinates of targets for future exploration.

\begin{tabular}{ccccc}
\hline Targets & Target A & Target A1 & Target B & Target B1 \\
\hline Eastings & 52500 & 52500 & $52700-52800$ & 52700 \\
Northings & $1319000-1320000$ & 1319000 & $1318000-1320000$ & 1319000
\end{tabular}




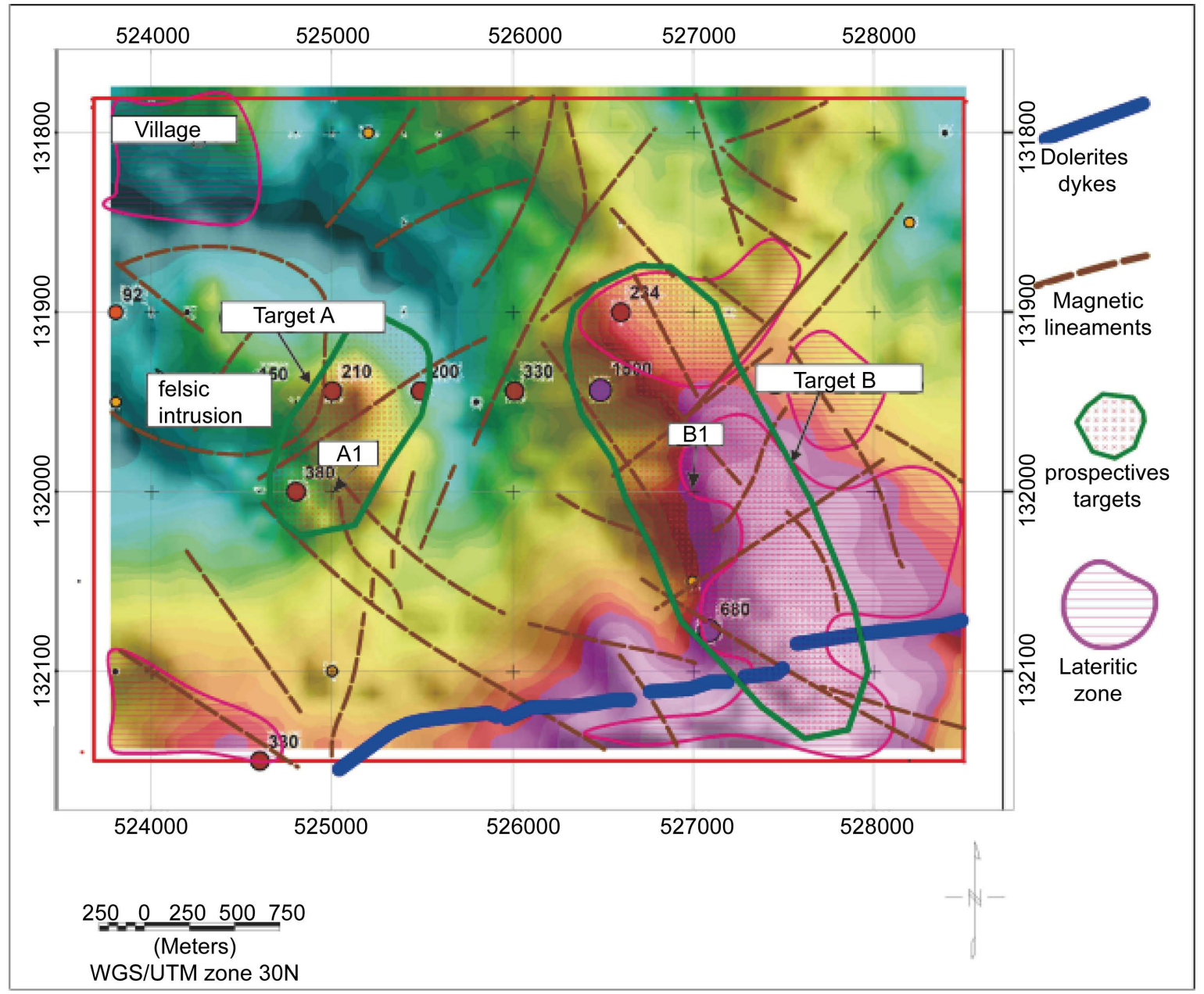

Figure 9. 2D integrated interpretation map showing two potential targets A and B of gold anomaly.

To know the origin of magnetic anomalies, its extension and its amplitude being a major structural element requires in-depth study of the electrical properties of the crust of the surrounding basin [22], and the fractional anomaly separation procedure are the important methods and techniques [23]. However, all primary gold deposit, prospects and showings that we studied in West Africa can be classified as orogenic type gold deposits [24].

\section{Conclusions}

As a conclusion, detecting the anomalies' sources location in the vast territory such as Kouremale area is to target high anomaly.

According to the $2 \mathrm{D}$ integrated interpretation image coming from the combination of the different maps (Figure 9), and referring to the geological information verified on the field, we have judged target B to be the best gold anomaly source in vast territory such as Kouremale.

The delimitation of the space of the target B from the geophysical and geochemical information confirms the existence of limited, restricted, and potential anomaly. 
This is confirmed by the gold content registered on the field. Therefore, the geochemical anomaly confirmed the magnetic anomaly. However, our field knowledge allowed specifying target $\mathrm{B}$. The distribution of the radioelements reflects the geochemistry and mineralogy of bedrock and regolith materials. $\mathrm{K}, \mathrm{U}$ and Th precipitate late in the igneous and volcanic crystallization sequence, usually observed on the field, even if the geochemical anomaly confirms for geophysical anomaly.

However, investigation of the geophysical and geochemical properties of rocks is essential for gold mineral assessment.

\section{Acknowledgements}

This study research has been financially supported by the Minister of Mines of Mali under (SYSMIN PROJECT 2002), that we would like to thank sincerely. Special thanks to my supervisor in state key laboratory of geological processes and mineral resources, China University of Geosciences, Wuhan. Thanks also all colleagues from National School of Engineers Abderhamane Baba TOURE of MALI for their advice.

\section{References}

[1] Kusnir, I. (1999) Gold in Mali. Acta Montanistica Slovaca, 4, 311

[2] Feybess, G. (2006) Notice explicative de la carte géologique de la republique du Mali à $1 / 200000$. [Explanatory Note of the Geological Map of the Republic of Mali at 1/200, 000.] Unpublished Report.

[3] Ibrahima Ballo, K.A.A.H., Guindo, B., Sanogo, L., Ouologuem, Y., Daou, G. and Traore, A. (2015) The Syama and Tabakoroni Goldfiefd, Mali. Ore Geology Reviews, 78, 578-585.

[4] Bassot J.P, Meloux, J. and Traore, H. (1981) Géologie du Mali. Unpublished Report, $17,18$.

[5] Teschner, B.A (2014) Orpaillage Pays for Everything: How Artisanal Mining Supported Rural Institutions Following Mali's Coup d'etat. Futures, 62, 141.

[6] Feybesse (2006) Geological Synthesis of the Malian Birimian Edition Sysmin.

[7] Sangaré, S. (1994) Les facteurs pétrogénitiques de l'aurification dans la zone de Kalana (sud du Mali). [The Petrogenic Factors of Aurification in the Area of Kalana (Southern Mali).] Unpublished Report.

[8] Mooney and Bleifurs (1953) Geophysique pour les geologies. [Geophysics for Geologists.] Tome2.

[9] Foulger, G.R. and Pierce, C. (2002) Geological Methods in Geology, 13.

[10] Ugalde, H.A., PGW, S.A., Reford, S.W., Paterson, Grant \& Watson Limited, Alessandro Colla Scintrex Ltd (2000) Radiometry and Magnetism: On the Usefulness of High-Resolution Airborne Magnetic and Radiometric Data in an Area of Sedimentary Cover: Calama West, Northern Chile. Summary, 3.

[11] Kearey and Brookes (1991) A “Typical” Ternary Diagram to Show the Distribution of Uranium, Thorium and Potassium (x10-4) in Selected Rock Types.

[12] Denith, M. and Mudge, S.T. (2014) Geophysics for the Mineral Exploration. 438.

[13] Airo, M.L. (2001) Aeromagnetic and Aeroradiometric Response to Hydrothermal Alteration. Surveys in Geophysics, 23, 273-302. 
[14] Mainguy, C. (2010) Natural Resources and Development: The Gold Sector in Mali. Ore Geology Reviews, 36, 123-131.

[15] Dunbar, P. and Sangare (2010) Technical Review of the Yanfoliala Gold Concession Mali, West Africa. 34.

[16] Stevenson, M.G., Mc Cullagh, M.J. and Cuss, R. (2000) The Application of GIS in the Interpretation of Radiometric and Electromagnetic Surveys to Mapping Geological and Environmental Features. 2-4.

[17] Reis, A.P. (2001) Soil Geochemical Propecting for Gold at Marrancos (Northern Portugal).

[18] Jordan, C. (2007) Using GIS and Statistics to Study Influences of Geology on Probability Features of Surface Soil Geochemistry in Northern Ireland.

[19] Sadeghi, M. (2014) Analysis and Mapping of Soil Geochemical Anomalies Implications for Bedrock Mapping and Gold Exploration in Giyani Area, South Africa. Journal of Geochemical Exploration, 154, 180-193.

[20] Mwenifumbo, C.J., Elliott, B.E., Jefferson, C.W., Bernius, G.R. and Pflug, K.A. (2003) Physical Rock Properties from the Athabasca Group: Designing Geophysical Exploration Models for Unconformity Uranium Deposit. Journal of Applied Geophysics, 119.

[21] Zarroca, M., Lineaires, R., Patricio, C., Lopez, V., Roque, C. and Rodriguez, R. (2014) Application of Electrical Resistivity Imaging ERI to Tailings Dam Project for Artisanal and Small-Scale gold Mining in Zaruna-Pprtovelo, Ecuador.

[22] Van Ngoc, P., Boyer, D. and Le Mouel, J.-L. (2000) Nouveaux arguments sur l'origine de l'anomalie magnétique du basin parisien (AMBP) d 'après les proprietes electriques de la croute. [New Arguments about the Origin of the Paris Basin Magnetic Anomaly (PBMA) from the Electrical Properties of the Crust.] Earth and Planetary Sciences, 331, 443-449. https://doi.org/10.1016/S1251-8050(00)01439-7

[23] Quentin Masurel, N.T., Mille, J., Ulrich, S., Hein, K.A.A., Hanssen, E., Kaisin, J. and Tessougue, S. (2015) The Yatela Gold Deposit in Mali, West Africa the Final Product of Long-Lived History of Hydrothermal Alteration and Weathering. Journal of African Earth Sciences, 86.

[24] Beziat, D., Dubois, M., Debat, P., Nikiema, S., Salvi, S. and Tollon, F. (2008) Gold Metallogeny in the Birimian Craton of Burkina Faso (West Africa). Journal of African Earth Sciences, 50, 215-233.

Submit or recommend next manuscript to SCIRP and we will provide best service for you:

Accepting pre-submission inquiries through Email, Facebook, LinkedIn, Twitter, etc. A wide selection of journals (inclusive of 9 subjects, more than 200 journals)

Providing 24-hour high-quality service

User-friendly online submission system

Fair and swift peer-review system

Efficient typesetting and proofreading procedure

Display of the result of downloads and visits, as well as the number of cited articles

Maximum dissemination of your research work

Submit your manuscript at: http://papersubmission.scirp.org/

Or contact ijg@scirp.org 